\title{
GROUTING AND INJECTION TECHNIQUES TO REPAIR CRACKS AND WATER LEAKAGE AT THE RENUKA DEVI TEMPLE, CHANDRAGUTTI, INDIA
}

\author{
POPRAVLJANJE RAZPOK S TEHNIKAMI OMETAVANJA IN \\ NABRIZGAVANJA V TEMPLJU RENUKA DEVI, CHANDRAGUTTI, \\ INDIJA
}

\author{
Gautham Hareendranathan ${ }^{1}$, Jeny Jairaj Stella ${ }^{1}$, Thirumalini Selvaraj ${ }^{1 *}$, \\ Nambirajan Murugan ${ }^{2}$ \\ ${ }^{1}$ Department of structural and geotechnical Engineering, School of Civil Engineering, Vellore Institute of Technology (VIT), \\ Katpadi Road, Tamil Nadu-632014, India \\ ${ }^{2}$ Archaeological Survey of India, Government of India, Dharohar Bhawan, 24, Tilak Marg, New Delhi-110001, India
}

Prejem rokopisa - received: 2019-10-16; sprejem za objavo - accepted for publication: 2020-04-28

doi:10.17222/mit.2019.250

\begin{abstract}
In the present research, characterization of ancient lime mortar from the 300-year-old Renukadevi Temple at Chandragutti, Karnataka, India, was carried out to propose an appropriate repair procedure for fixing a water leakage through the roof slab. The reason for the water seepage was a poor binder with the aggregate, with a ratio of 1:7. When the lime was washed away due to intense rain, the mortar became porous. XRD indicated that the original structure contains hydraulic lime with mineral-rich clay including calcite, aragonite, vaterite and tobermorite. The presence of tobermorite results in good performance and durability of the structure. The presence of organics rich in carbohydrate and protein was indicated by the FT-IR results. The repair mortar was simulated with an Oxal VP IT injection grout with $5 \%$ of fermented kadukkai and jaggery as carbohydrate-rich organic sources. The rheological performance of the organic grout was good during Marsh-cone and stability test. After 28 days, the compressive strength of the $1: 3$ mortar was $1.13 \mathrm{~N} / \mathrm{mm}^{2}$, suggesting it behaved like an artificial pozzolanic mortar with good strength. The organics played the main role in the carbonation of lime mortar and precipitation of tobermorite. A new organic grout compatible with the old mortar of the structure was prepared for the restoration.

Keywords: characterization study, organic additives, XRD, FT-IR, lime grout
\end{abstract}

V pričujočem članku avtorji predstavljajo raziskavo o karakterizaciji starodavne apnene malte na 300-letnem templju Renukadevi, ki se nahaja v Chandragutti, Karnataka, Indija. Raziskavo so izvedli, da bi našli oziroma predlagali ustrezno malto za popravilo razpok na strešnih ploščah, skozi katere pronica voda. Glavni razlog za pronicanje vode je slabo razmerje med vezivom in kamenimi agregati (1:7) tako, da je prišlo do izpiranja apna med močnim dežjem in povzročalo nastajanje porozne malte. Preiskave z rentgensko difrakcijo (XRD) so pokazale, da originalna struktura vsebuje hidravlični apnenec bogat z glinenimi minerali s kalcitom, aragonitom in vateritom, ki ga spremlja tobermorit. Posledica prisotnosti tobermorita je nastanek trdne in trajne strukture. S pomočjo infrardeče spektroskopije s Fourierovo transformacijo (FT-IR) so ugotovili tudi prisotnost organskih spojin bogatih na ogljikovih hidratih in proteinih. Simulacijo popravila so izvajali s postopkom nabrizgavanja Oxal VP - IT s $5 \%$ fermentirano raztopino rastline haritaki (tudi kadukkai) in nerafiniranim trsnim sladkorjem (Jaggery), ki sta oba bogata z ogljikovodiki. Testa stabilnosti in z Marshevim lijem sta pokazala dobre reološke lastnosti organske malte. Tlačna trdnost izdelanega materiala (mešanica malte in agregatov v razmerju 1:3) je bila po 28 dnevnem strjevanju podobna trdnosti umetne malte pozolana (vulkanski pepel), ki je znana po dobri trdnosti. Avtorji ugotavljajo, da organski dodatki igrajo pomembno vlogo pri karbonizaciji apnene malte precipitaciji tobermorita. Tako so avtorji pripravili za restavriranje templja novo ustrezno organsko malto s strukturo podobno starodavni malti.

Ključne besede: apnena malta, organski dodatki, karakterizacija, XRD, FT-IR

\section{INTRODUCTION}

Heritage buildings are deemed to mean those buildings that need to be preserved and conserved for their historic, architectural, aesthetic and cultural significance. They may be made of stones, bricks, earth, timber, lime, marbles or clay obtained from nature. ${ }^{1}$ There are many heritage buildings across the globe with beautiful earthen and lime-plaster finishes and decorative works. They were constructed using locally available materials. The passage of time can take its toll on these heritage buildings. Especially the damage to ancient structures and

*Corresponding author's e-mail:

p.thirumalini@yahoo.in (Thirumalini Selvaraj) monuments is mostly manifested in the form of cracks or voids, caused by drying shrinkage, natural weathering, plant growth and foundation settlement. ${ }^{2,3}$ The deterioration factor represents the effect of the change of a material under the action of many factors such as chemical, environmental, microbiological, biochemical, thermal actions, etc. Similarly, the environmental factors mainly include humidity, temperature variation, atmospheric pressure, precipitation, air pollution, soil settlement and artificial lighting. Modern repair and restoration practices seem to have decreased ${ }^{4}$ as time progressed; the invention of Portland cement in the $19^{\text {th }}$ century reduced the use of lime in construction and repair works. ${ }^{5-6}$ However, the high mechanical strength 
of cement is incompatible with low-strength lime mortar, which can increase damage instead of repairing it, and it is irreversible. ${ }^{1}$ Hence, the requirement for a physical, chemical and mechanical compatibility with ancient plasters and a retrieval of lime mortar ${ }^{7}$ and technology of its production is necessary. ${ }^{2}$

As a result, there are many different modern methods for repairing cracks such as injection, grouting, sealing, routing, stitching and plugging; the selection of a suitable method and materials play the main role in the restoration of historic buildings. Grouting has been widely used for repairing and strengthening of historic structures as it is believed by some researchers ${ }^{8,9}$ to be the best technique for strengthening stone or brick with lime-based mortars. They proposed three commercial injection-grouting categories, namely hydraulic pozzolan, cement grout and lime-cement grout used for strengthening historic buildings. The main criteria for selecting of the optimal grout mixture for restoration purposes include physical, chemical and mechanical characteristics.

With respect to flow conditions, reference article ${ }^{10}$ reports on the effect of an applied grout prepared by mixing an expansion agent, an anti-washout agent and a super plasticizer to reduce the leaching and segregation, which occur when a liquid and cement suspension are used. Article ${ }^{11}$ discusses reports on the development of grouting procedures and specific mix formulations for different types of masonry repair. Articles ${ }^{12,13}$ study different particle-size distributions simulating the infill of multi-leaf stone masonry walls, as well as the influence of different additives in the grouts. Specifically, the natural hydraulic-lime binders are considered, as they exhibit a chemical composition, physical and mechanical properties very similar to the historic materials, in

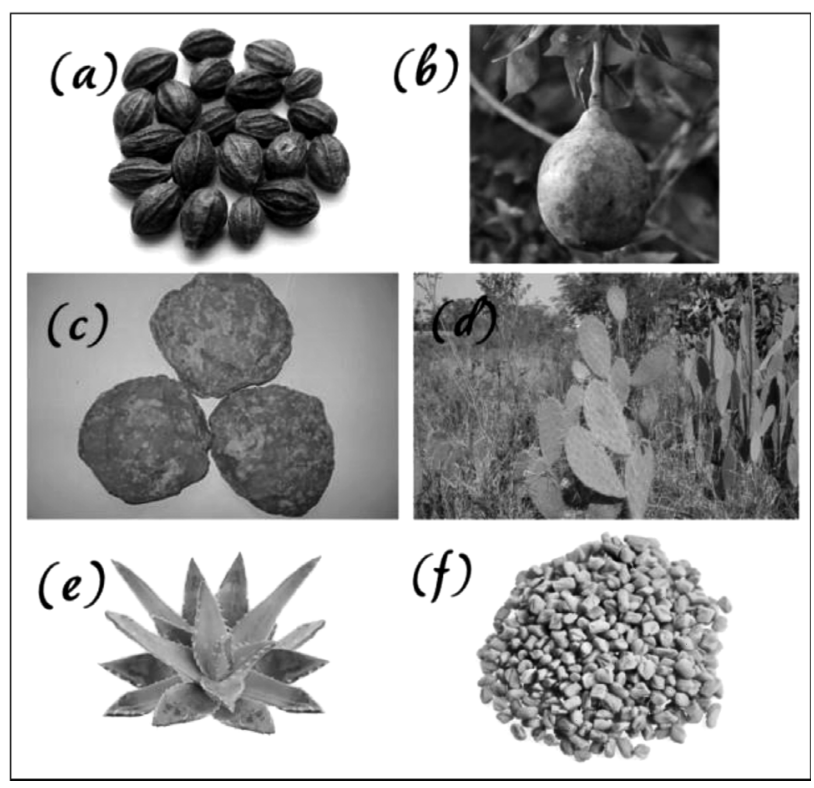

Figure 1: a) Kadukkai seeds, b) bel fruit, c) jaggery (unrefined sugar), d) cactus, e) aloe vera, f) fenugreek seeds comparison with cement or organic ones. The study reported in article $^{12}$ developed a lime-based grout material for earthen structures subjected to dynamic loads such as an earthquake. The grout showed good performance over fresh and hardened properties and an increased shear strength during cyclic loading. Article ${ }^{12}$ proposed a solution for repairing collapsed columns and weakened masonry walls, waterproofing with epoxy grouting and the provision of proper slopes by replacing the corroded ones using the lead-flashing methods.

In Mexico, there is some evidence that cactuses can be used for waterproofing, like the natural resins used in South America and Africa. Straw and dung after fermentation were used in Egypt and Sudan to improve hydrophobic properties. ${ }^{14}$ The same article discussed the rheological parameters including the grout fluidity, plastic viscosity, yield stress and flow time to control the composition of grout. Another important property is the granularity of the binder before mixing. Both rheology and penetrability depend on the flow of the grout. Research $^{15}$ deals with the effect of the environmental temperature on super-plasticized hydraulic lime-based grouts with a partial replacement of lime with silica fume. The grout performance is analysed in the fresh and hardened states by testing its rheological and mechanical behaviour, as well as its hydration-reaction kinetics.

Many countries revealed the repair of historic structures with mineral and chemical adhesives, binding the deteriorated mortars; likewise, India has a number of very rich and varied units of cultural heritage in the form of built structures and architectural monuments. The raw materials selected for the repair of cracks in architectural monuments was based on a characterization study of ancient organic mortars used in the structures. Although across the world these have been well investigated, not much investigation was done on the ancient plasters of

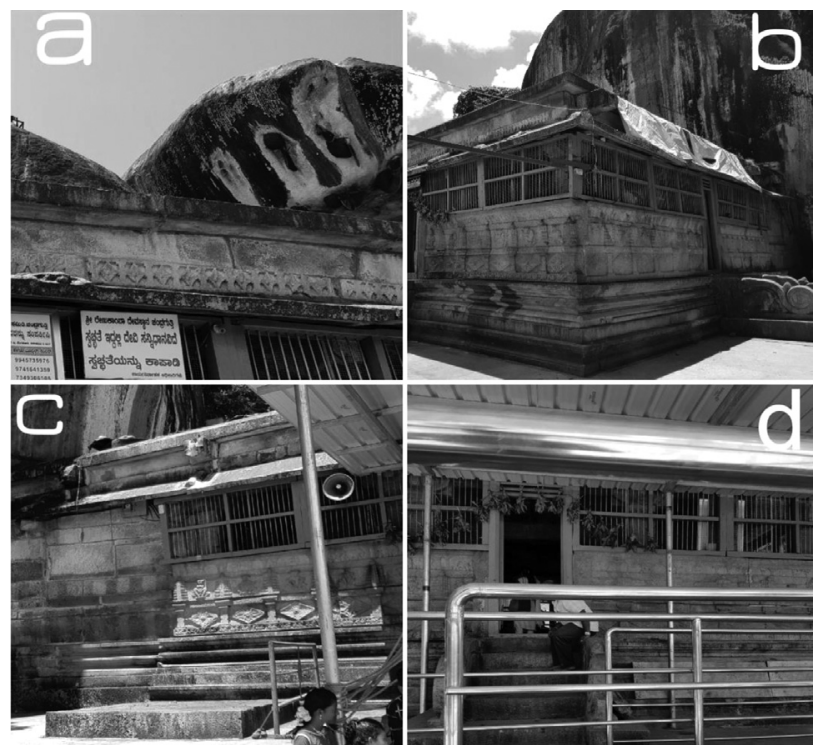

Figure 2: Renukadevi Temple, Karnataka, India: a) top view of the temple, b, c) side view, d) entrance to the temple 
the heritage structures in India. ${ }^{16}$ However, a few researched organic additives were used in lime mortars to alter their various properties, based on the regional availability. In South India, there is a traditional practice of preparing organic lime mortar with kadukkai (Termilinia chebula) and jaggery (unrefined sugar) as shown in Figure $1^{17-8}$ to repair the cracks and increase the mechanical properties.

A building that faces a water-logging problem is the 300-year-old Renukadevi Temple (Figure 2), located in Chandragutti, Karnataka, India. The roof of the temple has cracks that emerged due to the percolation of stagnant water through the material. This led to the formation of cracks on the roof, which started to damage the temple structure. The main aim of the present study is to characterize the ancient lime mortars used for the roof slab, using a mineralogical and acid-loss analysis. After adopting the ancient knowledge of using an organic additive for lime mortars as the repair material, we designed a compatible grout for waterproofing and strengthening the lime mortar.

\section{BACKGROUND AND CLIMATE OF CHANDRAGUTTI}

In ancient times, Chandragutti, shown in Figure 3, was a stronghold of Kadambas of Banavasi. It lies in Sorab Taluk in the Karnataka district, India. It lies at latitude $14.37^{`} \mathrm{E}$ and longitude $75.09^{`} \mathrm{~N}$. It is located at $848 \mathrm{~m}$ above mean sea level. Chandragutti has a tropical, wet and dry climate. The humidity ranges from $12 \%$ to $36 \%$. The summer season is between March to May and the average temperature is $20-35^{\circ} \mathrm{C}$. The rainy season in this region is from June to September, lasting for about 4 months. The temperature may drop to around $12{ }^{\circ} \mathrm{C}$. The rainfall is evenly distributed and most years are marked by an average rainfall of 1000-2500 $\mathrm{mm}$. Chandragutti is known for its lush greenery.

The Renukadevi Temple, which is 300 years old, is situated on the summit of an elevated spot. Due to this location, it is more exposed to climatic changes including heavy rainfall and large changes in the temperature during the summer and winter seasons. Over time, these drastic changes have degraded the structure. It has a large natural cave, approached by a flight of

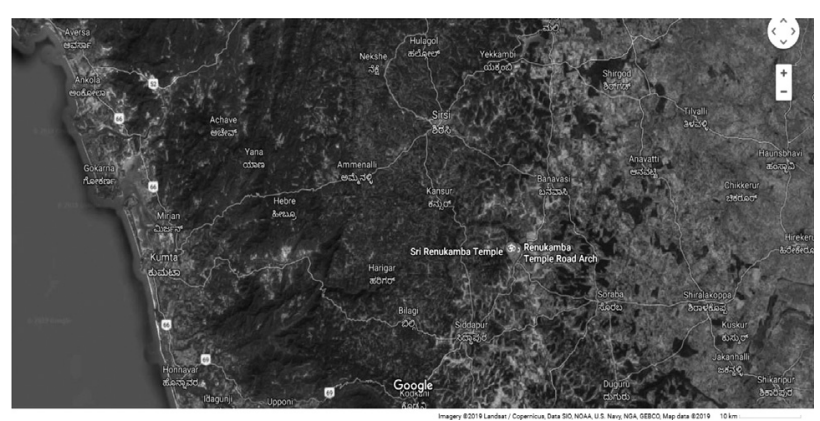

Figure 3: Location of Chandragutti, Karnataka, India steps, enshrining a small masked Shivalinga. The place has been associated with Saint Jamadagni and his wife Renuka. The Goddess Renuka Devi is worshipped here.

\section{METHODS AND MATERIALS}

\subsection{Sampling of ancient lime mortars}

During the past years, there has been a slow development of cracks (Figure 4) and voids on the top surface of the roof slab, leading to gradual water seepage from the roof to the walls of the temple. A total of five powdered or uncrushed lime-mortar samples were collected (Table 1). Three bedding lime mortars were collected from the rooftop and two lime plasters were collected from the walls of the temple. All the samples were collected from higher areas to avoid the effects of a capillarity rise of water and salts. Sufficient quantities of the samples collected were used for mineralogical analyses such as FT-IR and X-ray diffraction.

Table 1: Sample description

\begin{tabular}{|c|l|l|c|c|}
\hline S. No. & \multicolumn{1}{|c|}{$\begin{array}{c}\text { Sample } \\
\text { identification }\end{array}$} & $\begin{array}{c}\text { Material } \\
\text { collected }\end{array}$ & Location & $\begin{array}{c}\text { Quantity } \\
\text { (gms) }\end{array}$ \\
\hline 1. & External surface & $\begin{array}{l}\text { Bedding lime } \\
\text { mortar }\end{array}$ & Roof & 36.5 \\
\hline 2. & $\begin{array}{l}\text { Inner side of the } \\
\text { roof }\end{array}$ & $\begin{array}{l}\text { Bedding lime } \\
\text { mortar }\end{array}$ & Roof & 32.1 \\
\hline 3. & $\begin{array}{l}\text { Inner side of the } \\
\text { roof }\end{array}$ & $\begin{array}{l}\text { Bedding lime } \\
\text { mortar }\end{array}$ & Roof & 35 \\
\hline 4. & $\begin{array}{l}\text { Inner surface of } \\
\text { a wall }\end{array}$ & $\begin{array}{l}\text { Lime wall } \\
\text { plaster }\end{array}$ & $\begin{array}{c}\text { Wall } \\
\text { junction }\end{array}$ & 50 \\
\hline 5. & External surface & $\begin{array}{l}\text { Lime wall } \\
\text { plaster }\end{array}$ & $\begin{array}{c}\text { Wall } \\
\text { junction }\end{array}$ & 78.2 \\
\hline
\end{tabular}
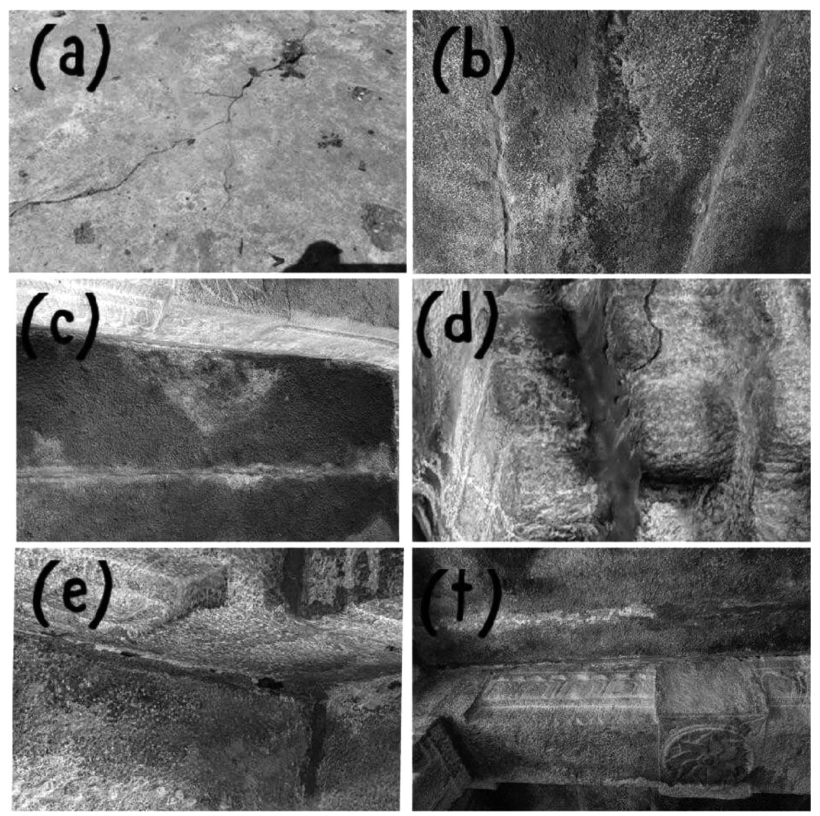

Figure 4: a) Cracks on the top surface of the roof, b, c, d) inner surface of the roof, e, f) junction of the roof and wall 


\subsection{Methods and materials}

The research was carried out in two stages, represented as part A and part B.

Part A: Characterization of the ancient lime mortars needed for preparing new grouts.

Part B: Preparation of grouts compatible with the ancient mortars and their validation by testing the rheological and mechanical properties of the prepared grouts.

Part C: Characterization of the ancient mortars at the Renuka Devi Temple, India

\subsubsection{Acid-loss test as per RILEM TC-167 Part A (Middendorf 2013) ${ }^{19}$}

The ratio of the binder and filling material is determined with an acid-loss analysis. Lime is used as the binder of aggregates, as the filling material. The ratio is determined by treating samples with dilute hydrochloric $(0.1 \mathrm{~N})$ acid. The samples were gently crushed and $10 \mathrm{~g}$ of gently crushed samples were mixed in a beaker of $500 \mathrm{~mL}$ along with $200 \mathrm{~mL}$ of distilled water (Figure 5). To that $30 \mathrm{~mL}$ of hydrochloric acid $(0.1 \mathrm{~N})$ was added; the mixture was continuously stirred for $1 \mathrm{~h}$ and then filtered out using filter paper. The residue remaining on the filter paper was the binder and the residue in the beaker was the aggregate.

\subsubsection{Chemical analysis of the ancient lime}

A chemical analysis was carried out to find the hydraulic character of the lime. Calcium oxide and magnesium oxide were quantified as the binder whereas ferrous oxide, aluminum oxide and silicon oxide were quantified as clay impurities. ${ }^{19}$

Using the formula 'hydraulic index = hydraulic index value' helped the selection of the right lime for grouting.

XRD analysis as per RILEM TC -167 Part B ${ }^{20}$

This is an instrumental technique, which gives qualitative information of the minerals present in the ancient lime-mortar samples. XRD was done using a desktop diffractometer using $\mathrm{Cu}-K_{\alpha}$ radiation and the results were interpreted using Bruker DIFFRACSUITE EVA software. ${ }^{7}$

\subsubsection{FTIR analysis}

FTIR (a Perkin-Elmer 1000 instrument) was used as a complementary test to confirm the results derived from $\mathrm{XRD}$. It provided qualitative information of the characteristic compounds present in a sample mortar and also determined the presence of carbonates, gypsum, calcium hydroxide, etc. In addition, there were also salts of nitrates, sulphate, etc., as well as organic compounds.

Part B: Preparation and testing of the grouts compatible with the ancient mortar

\subsubsection{Selection of lime}

The selection of lime was based on a chemicalanalysis study. It was found with the characterization study that hydraulic lime is suitable for the preparation of grout, which was in line with the belief of many researches that the materials traditionally used in several circumstances are to be considered. ${ }^{16}$ From several studies, it is clear that the performance of hydraulic lime is better than that of hydrated lime. ${ }^{21-23}$ A combination of both is also suggested by some researchers. Hence, hydraulic lime was considered as the injection grout and it also exhibited characteristics similar to those of the materials used originally.

\subsubsection{Preparation of organic water}

Two grout samples, namely the reference grout with water and organic grout were prepared. $500 \mathrm{~g}$ of fresh lime and $500 \mathrm{~mL}$ of water were mixed together in a bucket to prepare the reference grout. $2.5 \%$ of kadukkai and $2.5 \%$ of jaggery were crushed and soaked in one litre of water for 15 days to obtain the organic extract. $500 \mathrm{~g}$ of fresh lime and $500 \mathrm{~mL}$ of organic fermented water were mixed in a bucket to prepare a slurry of good consistency.

\subsubsection{Rheological properties}

The grout to be injected into the masonry should meet rheological properties by optimizing the fluidity and injection requirements ${ }^{24-26}$ by exhibiting enough compressive strength.

\subsubsection{Fluidity test with a Marsh cone (ASTM C 939, EN 447)}

A fluid grout should flow easily through the cracks and voids of a structure without excessive friction. Fluidity mainly depends on the grain-size distribution, shape of grains, specific surface of the solid phase, water content and mixing method. Fluidity can be increased with various methods, such as increasing the water content or adopting a proper mixing method. When the water content is increased, care should be taken to avoid bleeding. An adequate flow should be maintained while using low pumping pressures. During the injection period, fluidity of the grout is measured using a cone or grout spread. If the test method uses a cone, the time of discharge should be less than or equal to $25 \mathrm{~s}$ immediately after the mixing: $1.2 \mathrm{t} 0>=\mathrm{t} 30>=0.8 \mathrm{t} 0$, where $\mathrm{t} 0$ is the time of discharge immediately after the mixing and $\mathrm{t} 30<=25 \mathrm{~s}$ where $\mathrm{t} 30$ is the time of discharge $30 \mathrm{~min}$ after the mixing. No change in the fluidity by more than $20 \%$ within 30 minutes after the mixing is permitted. ${ }^{27}$

A Marsh cone was cleaned and used as shown in Figure 10. The slurry was poured through the Marsh cone at a constant rate. Another bucket was placed below the orifice of the cone and a stopwatch was used to record the time taken for the slurry to flow from the Marsh cone to the container at the bottom. The flow time for the cement-and-lime paste should not be longer than $15 \mathrm{~s}$. 
Table 2: Results of the acid-loss analysis

\begin{tabular}{|c|c|c|c|c|c|c|}
\hline Sample & Initial weight & $\begin{array}{c}\text { Acid loss } \\
(\mathrm{g})\end{array}$ & $\begin{array}{c}\text { Weight after the } \\
\text { acid loss }(\mathrm{g})\end{array}$ & $\begin{array}{c}\text { Weight of the sand } \\
\text { retained }(\mathrm{g})\end{array}$ & $\begin{array}{c}\text { Weight of the } \\
\text { binder }(\mathrm{g})\end{array}$ & $\begin{array}{c}\text { Binder/Aggregate } \\
\text { ratio }\end{array}$ \\
\hline 1 & 10 & 2.55 & 7.45 & 6.53 & 0.92 & $\mathbf{1 : 7}$ \\
\hline 2 & 10 & 2.7 & 7.3 & 6.7 & 0.98 & $\mathbf{1 : 6 . 8}$ \\
\hline 3 & 10 & 2.65 & 7.35 & 6.67 & 0.97 & $\mathbf{1 : 6 . 9}$ \\
\hline
\end{tabular}

\subsubsection{Stability test (ASTM 940) $)^{28}$}

A certain volume of grout was placed in a graduated test-tube, covered by a plastic film to avoid the evaporation. This test also allows us to evaluate the segregation by measuring layers with distinct colour and texture. The value of bleeding is given by the ratio between the volume of the water film formed at the surface of the grout after $3 \mathrm{~h}$ and $24 \mathrm{~h}$ and the initial volume of the grout. The EN standard indicates that this ratio should be lower than $2 \%$ after $3 \mathrm{~h}$. According to the method given in EN 447, ${ }^{29}$ the volume change of the grout after $24 \mathrm{~h}$ should be within a range of $-1 \%$ and $+5 \%$.

The grout was prepared by mixing $500 \mathrm{~g}$ of lime and $500 \mathrm{~mL}$ of water. This volume of grout was placed in a graduated test tube and observed after $3 \mathrm{~h}$ and $24 \mathrm{~h}$. The same procedure was repeated when preparing grout with $2.5 \%$ of kadukkai and $2.5 \%$ of jaggery.

\subsubsection{Compressive strength of the mortars}

Lime and river sand were mixed in a ratio of $1: 3$ by weight as per IS 712-1984. ${ }^{30}$ The water-to-lime ratio of 0.65 was maintained for all the mixtures. Lime mortar was prepared manually by mixing the raw materials continuously for about 10 minutes to get a uniform plastic mortar and then it was transferred to a cube mould with a size $50 \times 50 \times 50 \mathrm{~mm}$ as per (IS 6932). ${ }^{31}$ While filling the cube mould with freshly prepared lime mortar, a gentle press was created with a thumb for proper compaction and removal of air voids. After casting, the specimens were kept for curing at a temperature of $30 \pm 5{ }^{\circ} \mathrm{C}$ and relative humidity of $60 \pm 10 \%$, for the first $3 \mathrm{~d}$ in the mould and on the fourth day, the specimens were de-moulded and prepared for further curing until the $28^{\text {th }}$ day. On this day, the compressive strength of the specimens was measured using INSTRON 8801 equipment under a controlled strain rate of $2 \mathrm{~mm} / \mathrm{min}$.

\section{RESULTS AND DISCUSSIONS}

\subsection{Part A: Characterization of the ancient mortars}

\subsubsection{Acid-loss analysis}

The results of the acid-loss analysis are given in Table 2. The binder-aggregate ratio was found to be 1:7. In general, it is preferred to have a binder-to-aggregate ratio of $1: 2$ or $1: 3$ by weight. As water seepage was occurring for many years, the binder (Figure 5) would have leached out with the water and it is evident from the results that the ratio consists of less binder and more aggregate. This makes the lime mortar more porous and leads to further deterioration. According to reference, ${ }^{21} \mathrm{a}$ binder-aggregate ratio of 1:2-3 was reported for an ancient historic masonry in Crete, Greece, and a binderaggregate ratio of 1:3 was found for the masonry with highest strength and without any cracks or shrinkage. ${ }^{22}$ The reason for the durability of historical structures over the centuries was proper proportioning of the building materials (lime and sand), which is appropriate for the climate. $^{23}$

As discussed in article, ${ }^{32}$ for a place with a high percentage of relative humidity and no drastic change in the climatic conditions, the binder-to-aggregate ratio in a range of $1: 1$ to $1: 3$ is good. Reference study ${ }^{33}$ found a ratio of 1:3 for the mortar at the Vadakumnathan Temple, Kerala, which is in good condition and whose climatic condition is similar to that of Chandragutti. Hence, a ratio of 1:3 was adopted for preparing the repair grout.

\subsubsection{XRD and FT-IR Analyses}

The XRD results of the roof and walls are presented in Figures 6, 7. The results are presented in Table 3. Both the roof and wall samples show the presence of calcite, aragonite, vaterite, quartz, calcium oxide and tobermorite (calcium silicate hydrate). Hence, it is clearly understood from the formation of tobermorite that the lime was hydraulic as a tobermorite formation is only possible in the presence of clay impurities, which initiate the hydraulic reaction. Article ${ }^{34}$ discusses the presence of tobermorite in Roman marine concrete. The pozzolanic action of volcanic ash with lime in the presence of seawater significantly contributed to the durability of a 2000-year-old Roman marine concrete structure. The alkaline condition of seawater, carbonation reaction and cation exchange created an environment for the precipitation of tobermorite as explained by article. ${ }^{35}$

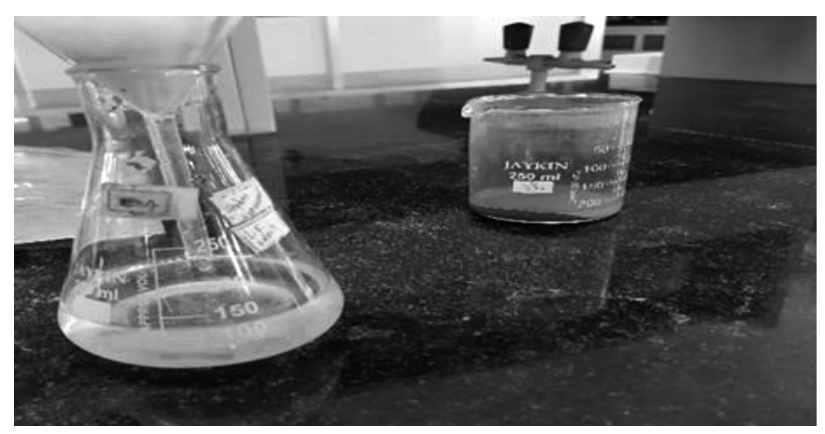

Figure 5: Acid-loss test 
G. HAREENDRANATHAN et al.: GROUTING AND INJECTION TECHNIQUES TO REPAIR CRACKS ...

Table 3: Summary of possible minerals from the XRD graphs

\begin{tabular}{|c|c|c|c|c|c|c|c|}
\hline Samples & Calcite & Aragonite & Vaterite & Portlandite & Tobermorite & Quartz & Lime \\
\hline Sample -1 & +++ & ++ & + & - & + & + \\
\hline Sample -2 & +++ & ++ & + & - & + & + \\
\hline Sample -3 & +++ & + & + & - & + & + \\
\hline Sample -4 & +++ & +++ & ++ & - & ++ & + \\
\hline Sample -5 & - & ++ & + & - & + & + \\
\hline
\end{tabular}

-: not present, + : present in traces, ++ : present at moderate levels, +++ : dominantly present

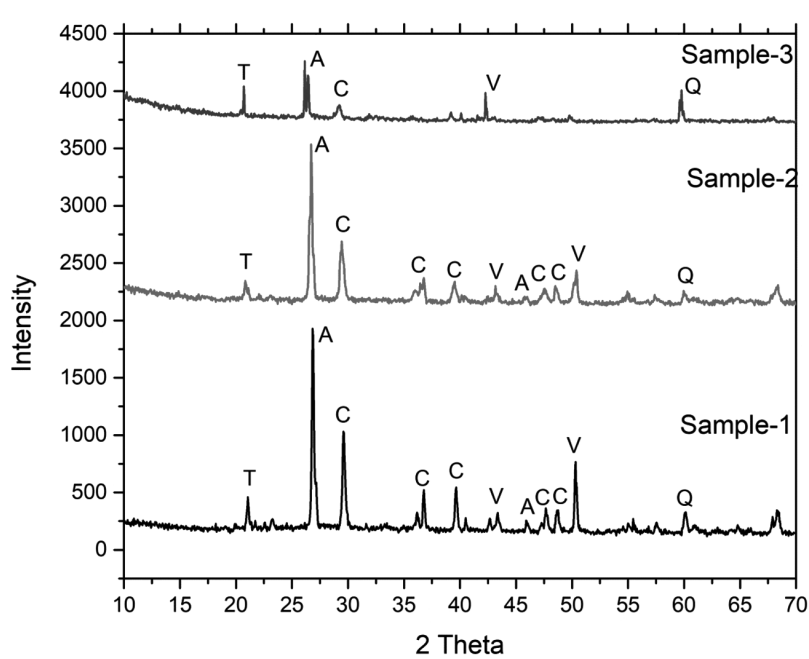

Figure 6: XRD of the roof samples: C: calcite, A: aragonite, $\mathrm{V}$ : vaterite, P: portlandite, T: tobermorite, Q: quartz

However, there is no possibility of adding volcanic ash as a pozzolanic matter in the presence of seawater to the Chandragutti lime mortars. Chandragutti lies in the Shivamogga belt known for its volcanic rock type and metamorphosed limestone rock (formed under high temperature and pressure). When such lime is used, there is a possibility of a formation of tobermorite. In addition,

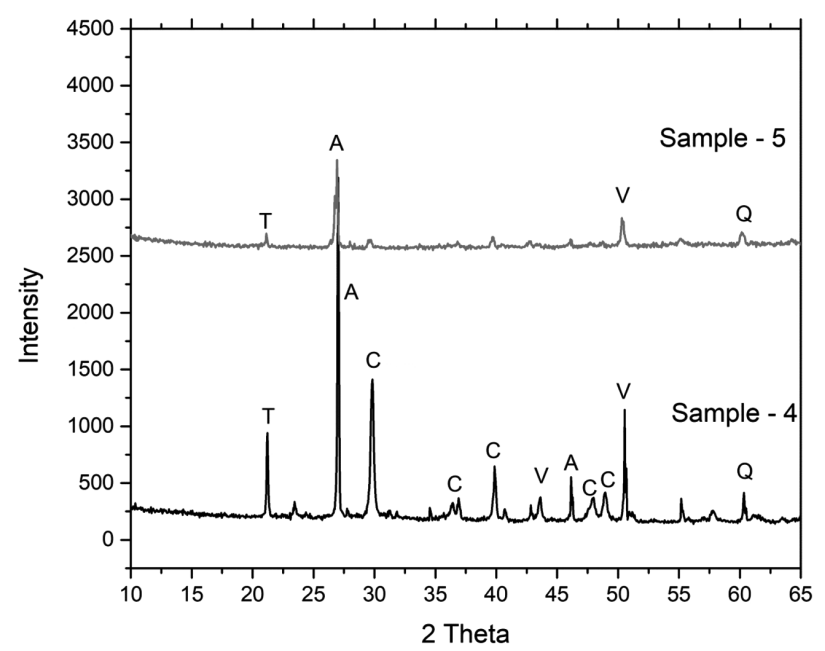

Figure 7: XRD of the wall samples: C: calcite, A: aragonite, $\mathrm{V}$ : vaterite, $\mathrm{P}$ : portlandite, T: tobermorite, Q: quartz

in the presence of organic additives in the form of sucrose, tobermorite can precipitate along with calcium carbonates from lime mortars. ${ }^{36,37}$ The FT-IR results presented in Figure 8 confirm the formation of the minerals identified with XRD, also indicating the presence of carbohydrates and amino acids in the mortars. Therefore, the presence of carbohydrates and proteins indicated by
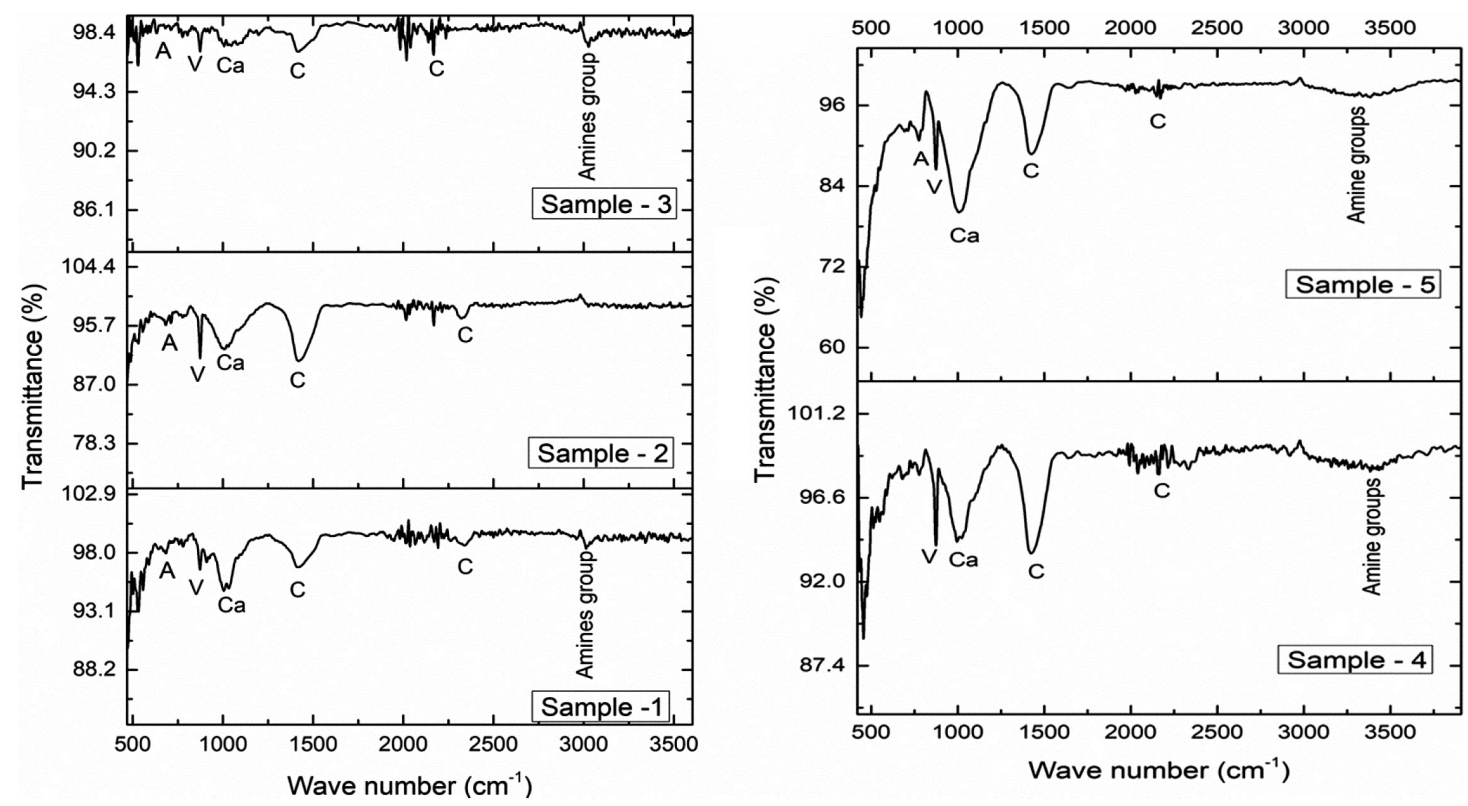

Figure 8: FT-IR of the roof samples: Ca: carbohydrate, C: calcite, A: aragonite, V: vaterite, P: portlandite, T: tobermorite, Q: quartz 
the FT-IR results supports the traditional practice of adding kadukkai (Terminalia chebula), a plant rich in carbohydrate, in the presence of jaggery (unrefined sugar) after the fermentation to lime mortars during the time of mixing.

Hence, in the Renuka Devi Temple mortars, these organics added to metamorphosed limestone in a saturated solution precipitated to form tobermorite. ${ }^{38}$ Further, in the case of hydraulic limes, there is a slow transformation of calcium silicate hydrate into a tobermorite undersaturated solution of organic matter. Hence, it is decided to prepare an organic grout with kaduaki and jaggery instead of regular mortars. Grout Oxal VP IT was selected, which is hydraulic lime. In general, in lime mortars without organic additives, the formation of calcite is higher compared with aragonite, whereas in this case, higher peaks of aragonite and a presence of vaterite in a smaller quantity again support the theory of adding organics. Metastable vaterite and aragonite prolong the longevity of the structures. ${ }^{39}$

However, from the FT-IR results, it was not possible to quantify the amount of organics. Thus, in discussion with local stapathis (people working on the Temple construction for generations) and based on a literature review pertaining to the Indian conditions, $5 \%$ of kadukkai and jaggery in one liter of water was considered for the study.

\subsubsection{Input for grout simulations}

Thus, hydraulic lime with a binder-to-aggregate ratio of $1: 3$ with a 5-\% organic additive including kadukkai and jaggery was recommended for the preparation of the grouts.

\subsection{Part B: Preparation of grouts compatible with the ancient mortars and their validation by testing the rheological properties of the grouts and the com- pressive strength of the prepared mortar}

\subsubsection{Preparation of compatible grouts}

\subsubsection{Selection of lime}

Usually, the hardening of lime mortar follows, either through carbonation or hydration, a process, in which the atmospheric carbon dioxide interacts with calcium hydroxide and forms stable calcium carbonate. The latter one indicates hydration, while the presence of clay impurities help to form calcium silica/alumina-related phases that help to improve the waterproof behaviour of lime mortars. ${ }^{7}$ After the characterization of the ancient lime mortars, the authors selected the appropriate binder to match the chemical composition of the ancient binder. In the grout, we found the presence of tobermorite, supporting the addition of clay impurities to lime mortars. ${ }^{40}$

Hence, we selected grout Oxal VP IT for the restoration, supplied by MC-Bauchemie - Construction
Chemistry, Germany. The binder comprises $\mathrm{CaO}(62 \%)$, $\mathrm{SiO}_{2}(25 \%), \mathrm{Al}_{2} \mathrm{O}_{3}(2.5 \%)$ and $\mathrm{Fe}_{2} \mathrm{O}_{3}(3 \%)$, confirming that the procured lime is hydraulic by nature (clay impurities are greater than $30 \%) .{ }^{16}$ It also contains lime powder stone appropriate for pumping, free from chloride, with a low viscosity and highly sulphate-resistant binder and can also be produced as M10-M20 mortar grades. The areas of application of this grout are filling in all kinds of cavities, injecting, backfilling and solidification of non-durable wet structures of natural stone masonry. The mixing ratio of lime $(\mathrm{kg})$ to water is $30: 9.6$ to $30: 13$, meaning that the water-to-lime ratio is $0.32: 0.43$. In the absence of air, the setting of hydraulic lime occurs, which makes it suitable for grouting internal voids. Consolidation develops quickly in the case of hydraulic lime, which is also more durable compared to the lime-based grout that is hydrated and which, in turn, is more preferable for deep voids or structures exposed to highly humid conditions.

\subsubsection{Organic water}

The water is the main liquid used for injecting grouts acts as a dispersive medium. However, there is a traditional practice of adding combined fermented kadukkai
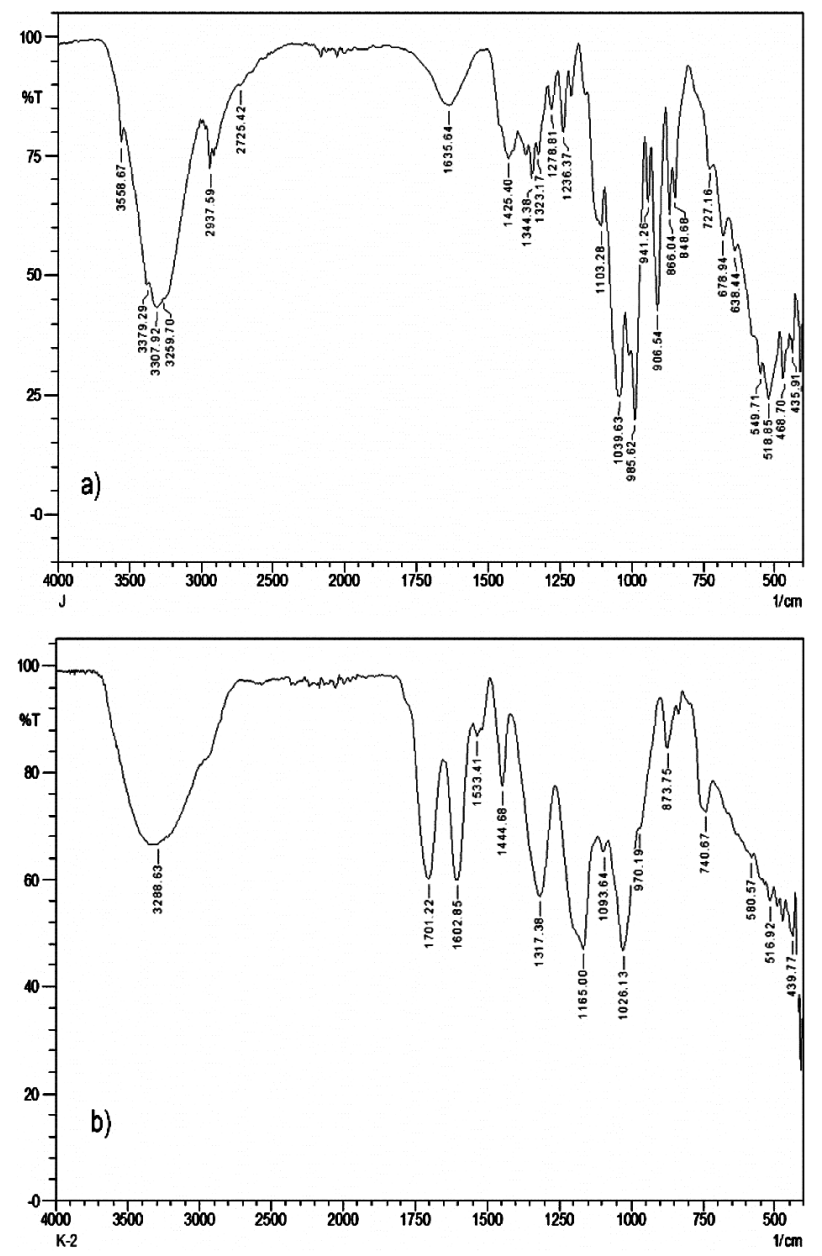

Figure 9: FT-IR graphs: a) jiggery, b) kadukai 
and jaggery water during the preparation of lime mortars; the same is true for the preparation of injection grouts. $5 \%$ of kadukkai and jaggery are mixed in a litre of water. They are fermented for 15 days in semi-open containers. ${ }^{41}$ The percentage of the organic water used in the grout mix plays the main role as an increase in the water content improves the injectability and flowability, while reducing the stability of the suspensions, causing bleeding along with the segregation ${ }^{9}$ and leading to cracking. To get more information, the authors conducted an FT-IR analysis of raw plant extracts of jaggery and kadukai as shown in Figure 9. The absorption spectra at $1026-1103 \mathrm{~cm}^{-1}$ are related to carbohydrates, while fatty acids in the form of polyvinyl acetate and esters are absorbed at 740 and $970-985 \mathrm{~cm}^{-1}$. A band of proteins is observed in a range of $1602-1635 \mathrm{~cm}^{-1}$. The presence of gallic acid is observed in kadukai at $1701.22 \mathrm{~cm}^{-1}$. The $\mathrm{C}-\mathrm{C}$ bond at $1425 \mathrm{~cm}^{-1}$ represents the aromatic rings and $727 \mathrm{~cm}^{-1}$ is related to $\mathrm{C}=\mathrm{C}$ benzene rings. ${ }^{42}$ Hydroxly ions are observed at $3300 \mathrm{~cm}^{-1}$. The conducted FT-IR analysis confirms the presence of carbohydrates and proteins in both jaggery and kadukai. Many authors discussed the interaction of plant extracts in lime mortar. Their addition improves the carbonation of lime mortar and proteins help to improve the durability of lime mortar. ${ }^{16}$

\subsubsection{Rheological properties}

\subsubsection{Fluidity test with a Marsh cone (ASTM C939, EN445))}

From Table 4, it is clear that the organic water meets the required criteria. The Marsh-cone test is a reliable and simple method (Figure 10). The principle is always the same, but the test geometry depends upon the standard and application. The fluidity of the material depends on the flow time, which is the time required by the material to flow out of the cone. ${ }^{27,29}$ The Mash-cone test is needed for determining the level of relative fluidity.

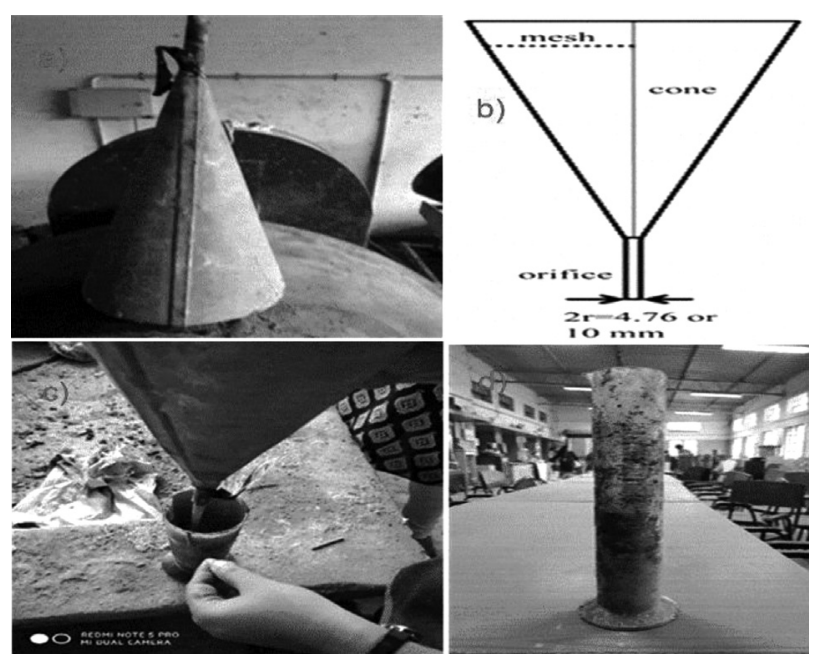

Figure 10: a), b), c) Marsh-cone test; d) stability
Table 4: Results of the Marsh-cone test

\begin{tabular}{|c|c|c|}
\hline S. No. & Description & $\begin{array}{c}\text { Time taken to discharge } \\
(\mathrm{s})\end{array}$ \\
\hline 1. & lime + water & 12.04 \\
\hline 2. & lime + organic water & 6.8 \\
\hline
\end{tabular}

\subsubsection{Stability test as per ASTM 940 (2010)}

The property of the grout to sustain its homogeneity during application and until its hardening is called stability. Stability ensures that bleeding and segregation are avoided. Low segregation helps to maintain the consistency of the grout. The volume change may be either an increase or decrease in the volume. The stability of a grout can be obtained experimentally though ASTM 940. ${ }^{28}$ With both water and organic water addition, there is no segregation of the binder and liquid and no distinct colour or texture change (Figure 10).

\subsubsection{Compressive strength of the mortars}

The average value of the compressive strength of lime mortars was found to be $1.38 \mathrm{~N} / \mathrm{mm}^{2}$ (Table 5). The mortars have a density of $1.7 \mathrm{~g} / \mathrm{cm}^{3}$ and based on the compressive-strength values, a comparison was made. As explained by Moropoulou (IS 6932-1973), the organic grout used at the Renukadevi Temple behaves like artificial pozzolanic mortars with a binder-to-aggregate ratio of $1: 3$, compressive strength of $1.38 \mathrm{~N} / \mathrm{mm}^{2}$ and density of $1.7 \mathrm{~g} / \mathrm{cm}^{3}$. This implies that the organic addition to lime mortars plays the role of a pozzolan, alters the hydrated phase of the mortar and enhances its strength and durability.

Table 5: Compressive strength of the lime grout

\begin{tabular}{|c|c|}
\hline Description & $\begin{array}{c}\text { Compressive strength } \\
\left(\mathrm{N} / \mathrm{mm}^{2}\right)\end{array}$ \\
\hline Sample -1 & 1.37 \\
\hline Sample -2 & 1.40 \\
\hline Sample -3 & 1.38 \\
\hline Average & 1.38 \\
\hline
\end{tabular}

\section{CONCLUSIONS}

The lime mortar at the Renuka Devi Temple, Chandragutti, was characterized so that we could prepare a compatible lime grout to arrest water seepage from the roof slab of the structure. The binder-to-aggregate ratio of the lime mortar was 1:7, which was very poor. FT-IR results indicate the presence of carbohydrate and protein-rich organics in the ancient mortars where the binder was hydraulic by nature. Based on the regional availability, $5 \%$ of fermented kadukkai and jaggery extracts, as herbs, along with hydraulic lime were used as the repair grout. With the results of FT-IR, the presence of carbohydrates was confirmed. Hence, the feasibility of using kadukkai and jaggery is justified. Simulation mortar-to-binder ratio of 1:3 shows a good compressive strength on the $28^{\text {th }}$ day. The formation of 
tobermorite recorded with XRD indicates that the mortars are good in strength and durability. The lime grout met all the requirements, such as a fluidity of less than $6 \mathrm{sec}$, and showed no segregation instability. Hence, the lime seems to behave like an artificial pozzolanic lime in the presence of organics and the prepared grout is effective in repairing cracks of the temple structure.

\section{Conflict of interest statement}

On behalf of all the authors, the corresponding author states that there is no conflict of interest.

\section{REFERENCES}

${ }^{1}$ Handbook of conservation of heritage buildings: A guide, Central Public Works Department, Falcon Graphics, India, 2013, 104

${ }^{2}$ A. Luque, G. Cultrone, E. Sebastián, The use of lime mortars in restoration work on architectural heritage, Materials, Technologies and Practice in Historic Heritage Structures, 11 (2010), 197-207, doi:10-1007/978-90-481-2684-2_11

${ }^{3}$ K. A. Gour, R. Ramadoss, T. Selvaraj, Revamping the traditional air lime mortar using the natural polymer-Areca nut for restoration application, Construction and Building Materials, 164 (2018), 255-264, doi:10.1016/j.conbuildmat.2017.12.056

${ }^{4}$ R. A. Silva, O. Domínguez-Martínez, D. V. Oliveira, E. B. Pereira, Comparison of the performance of hydraulic lime- and clay-based grouts in the repair of rammed earth, Construction and Building Materials, 193 (2018), 384-394, doi:10.1016/j.conbuildmat.2018. 10.207

${ }^{5} \mathrm{~K}$. Van Balen, Weaker can be better: learning from the past contributes to sustainable construction technology with lime, International Building Lime Symposium, National Lime Association, Orlando, Florida, 2005

${ }^{6}$ R. R. J. V. Hees, L. Binda, I. Papyianni, E. Toumbakari, Damage analysis as a step towards compatible repair mortars, Characterization of old materials with respect to their repair, RILEM REPORT, France, 2006, 107-152

${ }^{7}$ A. Moropoulou, A. Bakolas, S. Anagnostopoulou, Composite materials in ancient structures, Cement and Concrete Composites, 27 (2005) 2, 295-300, doi:10.1016/j.cemconcomp.2004.02.018

${ }^{8}$ I. Papayianni, V. Pachta, High performance lime-based grouts for repair of historic masonries, International conference on structural analysis of historical constructions (SAHC), Wroclaw, Poland, 2012, $15-17$

${ }^{9}$ M. Uranjek, R. Žarnić, V. Bosiljkov, Strengthening of heritage buildings by means of grout injection -problems and solutions, Proc. of $2^{\text {nd }}$ Conference on Historic Mortars - HMC 2010 and RILEM TC 203-RHM final workshop, 2010, 769-777

${ }^{10}$ D. Kim, S. Jung, K. Cha, Evaluation of the performance of grouting materials for saturated riprap, Materials, 6 (2013) 12, 5713-5725, doi:10.3390/ma6125713

${ }^{11}$ U. Mueller, L. Micoll, P. Fontana, A lime based grouting material for repair of earthen structures, International Conference on Building with Earth, Weimar, Berlin, Germany, 2016, 9

${ }^{12} \mathrm{~S}$. Sandbhor, R. Botre, A systematic approach towards restoration of heritage buildings - a case study, International Journal of Research in Engineering and Technology (IJRET), 2 (2013) 3, 229-238

${ }^{13}$ M. P. Schuller, R. H. Atkinson, J. T. Borgsmiller, Injection grouting for repair and retrofit of unreinforced masonry, Proceedings of the 10th International Brick and Block Masonry Conference, Calgary, Canada, 1994, 549-558

${ }^{14}$ R. Eires, A. Camoes, S. Jalali, Ancient materials and techniques to improve the earthen building durability, Key Engineering Materials, Trans Tech Publications Ltd., 634 (2015), 357-366, doi:10.4028/ www.scientific.net/KEM.634.357
${ }^{15}$ M. R. Valluzzi: Requirements for the choice of mortar and grouts for consolidation of three-leaf stone masonry walls, International RILEM Workshop on Repair Mortars for Historic Masonry, Delft University of Technology, The Netherlands, 2005, 382-397

${ }^{16}$ R. Ramadoss, T. Selvaraj, N. Taher, Analysis of ancient lime plasters - Reason behind longevity of the Monument Charminar, India, a study, Journal of Building Engineering, 20 (2018), 30-41, doi:10.1016/j.jobe.2018.04.010

${ }^{17}$ T. Selvaraj, S. K. Sekar, R. Ramadoss, Revealing the ancient secret of lime mortar exposed to marine environment used in and around Padaleeswarar temple, Tamil Nadu, 4th Historic Mortars Conference, Santorini, Greece, 2016, 93-103

${ }^{18}$ T. Selvaraj, S. K. Sekar, B. Balu, Bio-inorganic composites as repair mortar for heritage structures, Journal of Structural Engineering (Madras), 42 (2015) 4, 294-304

${ }^{19}$ B. Middendorf, J. J. Hughes, K. Callebaut, G. Baronio, I. Papayianni, Investigative methods for the characterisation of historic mortars Part 2: Chemical characterization, Materials and Structures, 38 (2005) 8, 771-780, doi:10.1007/BF02479290

${ }^{20}$ B. Middendorf, J. J. Hughes, K. Callebaut, G. Baronio, I. Papayianni, Investigative methods for the characterisation of historic mortars Part 2: Mineralogical characterization, Materials and Structures, 38, (2005) 8, 769-771, doi:10.1007/BF02479289

${ }^{21}$ P. Maravelaki-Kalaitzaki, A. Bakolas, I. Karatasios, V. Kilikoglou, Hydraulic lime mortars for the restoration of historic masonry in Crete, Cement and Concrete Research, 35 (2005) 8, 1577-1586, doi:10.1016/j.cemconres.2004.09.001

${ }^{22}$ J. Lanas, J. I. Alvarez-Galindo, Masonry repair lime-based mortars: factors affecting the mechanical behavior, Cement and Concrete Research, 33 (2003) 11, 1867-1876, doi:10.1016/S0008-8846(03) 00210-2

${ }^{23}$ B. Ipekoglu, H. Boke, O. Cizer, Assessment of material use in relation to climate in historic buildings, Building and Environment, 42 (2007) 2, 970-978, doi:10.1016/j.buildenv.2005.10.029

${ }^{24}$ P. A. Jeffs, Core consolidation of heritage structure masonry walls \& foundations using grouting techniques - Canadian case studies, Proceedings of the 9th Canadian Masonry Symposium, University of New Brunswick, Canada, 2001, 4-6

${ }^{25}$ M. H. Mohammed, R. Pusch, S. Knutsson, G. Hellstr, Rheological properties of cement-based grouts determined by different techniques, Engineering, 6 (2014) 5, 217-229, doi:10.4236/eng.2014. 65026

${ }^{26}$ S. Kazemain, A. Prasad, B. B. K. Huat, Rheological behavior of grout in context of Newtonian and non-Newtonian fluid, EJEG, 15 (2010), 1104-1115, doi:10.1201/b12748-42

${ }^{27}$ ASTM C 939-02 Standard test method for flow of grout for preplaced-aggregate concrete (Flow cone method), ASTM international, West Conshohocken, United States

${ }^{28}$ ASTM (2010) Standard test method for expansion and bleeding of freshly mixed grouts for preplaced-aggregate concrete in the laboratory

${ }^{29}$ EN447 (2007) Grout for prestressing tendons - Test Methods, British Standards Institution, London, United Kingdom

${ }^{30}$ IS 712 (1984), Indian Standards, Specification for Building Limes, Bureau of Indian Standard, New Delhi, India

${ }^{31}$ IS 6932 (Part VII) (1973): Methods of tests for building limes Determination of compressive and transverse strength, Bureau of Indian Standards, New Delhi, India

${ }^{32}$ A. Moropoulou, A. Bakolas, P. Moundoulas, E. Aggelakopoulou, S. Anagnostopoulou, Strength development and lime reaction in mortars for repairing historic masonries, Cement and Concrete Composites, 27 (2005), 289-294, doi:10.1016/j.cemconcomp. 2004.02.017

${ }^{33}$ T. Selvaraj, R. Ramadoss, S. K. Sekar, M. Nambirajan, Knowing from the past - Ingredients and technology of ancient mortar used in Vadakumnathan temple, Tirussur, Kerala, India, Journal of Building Engineering, 4 (2015), 101-112, doi:10.1016/j.jobe.2015.09.004 


\section{G. HAREENDRANATHAN et al.: GROUTING AND INJECTION TECHNIQUES TO REPAIR CRACKS ...}

${ }^{34}$ M. D. Jackson, S. R. Mulcahy, H. Chen, Y. Li, Q. Li, P. Cappelletti, H. R. Wenk, Phillipsite and Al-tobermorite mineral cements produced through low-temperature water-rock reactions in Roman marine concrete, American Mineralogist, 102 (2017) 7, 1435-1450, doi:10.2138/am-2017-5993CCBY

${ }^{35}$ E. M. M. A. Cantisani, A. Cecchi, I. Chiaverini, F. A. B. I. O. Fratini, C Manganelli Del Fá, E. Pecchioni, S. Rescic, The binder of the Roman concrete of the Ponte di Augusto at Narni (Italy), Per. Mineral, 71 (2002) 1, 113-123

${ }^{36}$ A. Hartmann, D. Schulenberg, J. C. Buhl, Investigation of the transition reaction of tobermorite to xonotlite under influence of additives, Advances in Chemical Engineering and Science, 5 (2015) 2, 197-214, doi:10.15488/1530

${ }^{37}$ J. R. Houston, R. S. Maxwell, S. A. Carroll, Transformation of meta-stable calcium silicate hydrates to tobermorite: reaction kinetics and molecular structure from XRD and NMR spectroscopy, Geochemical Transactions, 10 (2009) 1, 1-14, doi:10.1186/14674866-10-1

${ }^{38}$ A. Moropoulou, A. Cakmak, K. C. Labropoulos, R. Van Grieken, K. Torfs, Accelerated microstructural evolution of a calcium-silicate- hydrate $(\mathrm{CSH})$ phase in pozzolanic pastes using fine siliceous sources: Comparison with historic pozzolanic mortars, Cement and Concrete Research, 34 (2004) 1, 1-6, doi:10.1016/S0008-8846(03) 00187-X

${ }^{39}$ T. Selvaraj, R. Ramadoss, Analysis and characterisation of third century ancient mortars at subramanyaswamy temple rediscovered after the 2004 tsunami near mamallapuram shore, India, International Journal of Conservation Science, 9 (2018) 1, 25-38

${ }^{40}$ A. Moropoulou, A. Bakolas, K. Bisbikou, Characterization of ancient, byzantine and later historic mortars by thermal and X-ray diffraction techniques, Thermochimica Acta, 269 (1995), 779-795 doi:10.1016/0040-6031(95)02571-5

${ }^{41}$ S. Jayasingh, T. Selvaraj, Study on Carbonation Initiated by Organics in Traditional Lime Mortar, Structural Analysis of Historical Constructions, Springer, Cham., 2019, 421-428

${ }^{42}$ T. Selvaraj, S. K. Sekar, Heritage lime mortar characterization and simulation, Doctoral dissertation, School of Mechanical and Building Sciences, VIT University, India, 2015 